\title{
Robbing Peter . . . Balancing Collection Development and Reference Responsibilities
}

\section{David G. Null}

This article examines some of the problems faced by librarians who have both collection development and reference responsibilities. Major concerns include balancing demands on one's time, unclear supervisory lines, and misunderstanding of the collection development process. Suggestions include establishing formal reporting lines for both reference and collection development, increasing communication among supervisors, training selectors more effectively, and heightening awareness of the necessity for better organization in collection development.

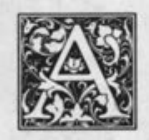

cademic librarianship, like many other academic fields, seems to be becoming less specialized, at least in many medium- and small-sized libraries. Increasingly, librarians face a multiplicity of jobs, e.g., reference work, collection development, cataloging, and teaching. Most literature on library jobs, however, tends to present librarians as single-task specialists. In reality, librarians regularly perform two or more jobs. The problems inherent in trying to juggle multiple responsibilities are of considerable concern. One of the most common arrangements is the combining of reference and collection development. This dual responsiblity usually takes one of two forms: bibliographers (subject specialists) who also do reference, or reference librarians who also do collection development. Several articles have recently focused on dual assignments from the point of view of a collec- tion development officer. ${ }^{1}$ This article however, examines reference librarians who have selection responsibilities.

Laurie Linsley, in a paper given at the third Association of College and Research Libraries (ACRL) conference, lists the reference/collection development split as the most common dual assignment in the seventy-two academic libraries she surveyed. A study conducted in 1983 by Nancy Emmick and Luella Davis shows that 37.9 percent of academic reference librarians also perform collection development work, and 70.3 percent have liaison assignments with faculty. A 1983 survey by the Discussion Group on Reference Services in Large Research Libraries shows that two-thirds of the reporting reference departments had librarians with substantial collection development duties. A 1987 article on training new reference librarians reports that these people spent about 12 percent of their time on col-

David G. Null is Head, Reference, and Coordinator of Social Science Collection Development at the University of New Mexico, Albuquerque, New Mexico 87131. 
lection development activities. ${ }^{2}$ Obviously, many reference librarians also have collection development duties, and from the recent interest in this topic, perhaps best exemplified by the newly formed Collection Development and Evaluation Section (CODES) within the Reference and Adult Services Division (RASD), many librarians are experiencing the pressures of handling more than one responsibility.

Having one person do several jobs in the library is not necessarily dysfunctional. In the last several years there has been a good deal of discussion about an integrated model of academic librarianship, particularly in medium- and small-sized libraries. In such a model "subject specialists or scholar librarians do collection development and provide in-depth reference service including bibliographic instruction and online searching in their fields of expertise. ${ }^{\prime \prime 3}$ While many librarians find the integrated approach appealing, Patricia Swanson points out that "there is a contradiction in the integrated model in that on the one hand, we are expected to do everything and on the other hand quality work environments are supposed to identify and nurture our individual talents and strengths. ${ }^{\prime 4}$ In other words, although all of us do not do everything equally well, and probably do not want to, we often are expected to do so, and we are evaluated as though we do.

This problem is compounded in the reference and collection development split by the fact that reference has a long and fairly stable tradition. Reference librarians know what they are expected to do and how to do it. This is not the case for collection development. Not long ago, the trend in collection development was toward subject bibliographers, but today that structure is not as prevalent. Indeed, as a recent article by Jeanne Sohn points out, there is no clear pattern of how collection development is organized in Association of Research Libraries (ARL) libraries. Not only is there no clear pattern, but almost half of the collection development officers who responded to Sohn's survey were dissatisfied with the way collection development was handled in their institutions-even if that structure had changed recently. ${ }^{5}$ One can argue, and many people have, for or against full-time bibliographers as opposed to part-time selectors, but the reality is that many librarians have multiple responsibilities. ${ }^{\circ}$

There are several problems inherent in attempting to handle multiple responsibilities in a library or any other type of workplace. One of the most significant and difficult is managing all of the demands on one's time. Most reference librarians work at a reference desk, perform online literature searches, give library instruction sessions, and prepare handouts or bibliographies. In addition to these responsibilities, one might find such other duties as collection development, interlibrary loan, and government publications.?

What almost always happens in such situations is that when push comes to shove, collection development gets shoved. Collection development rarely has the immediacy of reference work. One can always order a book tomorrow or next week, but one cannot always put off a tour, or an online search, or one's regularly scheduled hours on the reference desk. A 1979 study of public services librarians conducted at Brigham Young University shows that "few generalizations can be made except that all four types of [public service] librarians spend less time on acquisitions than on reference. ${ }^{18}$

The other major problem is supervision. Usually a reference librarian who also does collection development reports to a head of reference. Rarely does a reference librarian report to a collection development officer. Sohn's article points out that this is a major problem for collection development officers without official supervisory authority who must coordinate the work of many part-time selectors. ${ }^{9}$ Some librarians are fortunate enough to report formally to a head of reference for reference duties and to a collection development officer for selection responsibilities, but that administrative pattern is not prevalent.

Formal reporting lines for collection development, however, can help to legitimize selection and allow selectors whose primary assignment is elsewhere to feel 
more secure about the time that they devote to collection development. Such reporting may also help librarians with selection and reference responsibilities to be relieved of some reference duties if they can show that they officially are doing collection development. Similarly, clearly defined reporting lines may help with matters such as access to support staff. Anyone who does collection development knows that much clerical work is needed. Reporting to a collection development officer may make it easier to get support staff outside of the reference department to help with such tasks.

Formal reporting lines and job descriptions allow librarians with selection and reference responsibilities to know which criteria they are being evaluated on and what they must do to meet their supervisors' expectations. Such reporting also helps assure the selector of more input into decision and policy making. This is especially important when one person is reporting to, and being evaluated by, two or more supervisors. Clearly, the head of reference and the collection development officer must know each other's goals and objectives. They need to check for complementary or opposing goals and objectives, and they should attempt to see whether a librarian doing both reference and collection development is able to meet all of the stated objectives. Similarly, selectors who are primarily reference librarians, and do not report to a collection development officer, should somehow be involved in goals and objectives planning for collection development.

There also has to be good communication and coordination at the higher levels of administration, either department head or assistant/associate dean level. A problem with collection development is that, on the one hand, it is becoming more visible, often through promotion of a person to an assistant/associate dean in charge of collection development; while on the other hand, this person often has little authority or line responsibility. ${ }^{10}$ This may be due to an unwillingness of traditional library administrations to change. In order for a person to be made an associate/assistant dean for collection development and given line responsibility for selectors, someone else in the organizational structure must relinquish some authority and power. Administrators may need to think more about how their roles affect those below them and the library as a whole and not so much about their own power bases. ${ }^{11}$

One potential way of handling multiple reporting lines is through matrix management. Indeed, according to one article, "the dominant characteristic of matrix structure .... is the dual reporting relationship. ${ }^{\prime \prime 2}$ There are several difficulties with a matrix structure, however, including a tendency to defer making decisions, and a danger of power struggles among multiple bosses trying to gain control of library units. David W. Lewis has suggested an organizational paradigm using a modified professional bureaucracy in which middle management is reduced and a large support staff is provided to free professionals from routine tasks. This structure might allow greater freedom for a librarian to do more than one job. ${ }^{13}$

In addition to clear reporting lines, the mention of collection development duties in a librarian's job description and assignment of a percentage of a person's time or work load to collection development may be a good idea. Not that one should feel compelled to follow slavishly the percentage named, but once again a clearly defined amount of time devoted to collection development allows a selector to feel better able to give that time to collection development. An assigned amount of time might also lead administrators to realize that a person is officially doing collection development, and, just as importantly, it may help part-time selectors to understand that administrators have a real commitment to collection development.

Supervisors should be aware that clear goals, objectives, and job descriptions create a positive effect on an employee's morale and performance. Personnel literature is inconsistent about what causes job stress and dissatisfaction, but at least one library study suggests that role conflict (where expectations are in conflict) and role ambiguity (unclear expectations) adversely affect job satisfaction. ${ }^{14}$ 
Unfortunately for those who must balance both reference and collection development duties, helpful literature is sparse. There is considerable literature on time management, but it appears to focus primarily on how to keep one's desk clean and affords few hints on how to juggle two or more primary tasks.

Much of the problem for part-time selectors is showing how much time they devote to collection development and the value of that investment. Reference work has a long history and an established importance in librarianship, and it is somewhat easier to quantify than collection development work. One can fairly easily put into figures the amount of time spent on the reference desk, running an online search, and talking to a class. Attempting to quantify collection development work-time spent consulting catalogs, reviews, approval plans, talking to faculty and students, and examining books on the shelves-is a difficult task. ${ }^{13}$ This ignores times when one is doing both functions, e.g., going over approval slips or book reviews while sitting at the reference desk. Often the problem is to convince people who have never done collection development that such activities are worthwhile and essential for the library as a whole.

Part of the problem may lie with those who do collection development. One of the oddities is that while almost everyone will admit it is a central mission of the library, many librarians and administrators seem to feel anyone can do it, it does not take much training or background, and one does not really need to pay a lot of attention to it. While it may be true that anyone can do collection development, just as anyone can do cataloging, not everyone can do collection development well. Perhaps those of us in collection development or management have not done enough to train selectors thoroughly in the techniques of good collection development, evaluation, and management. Nor have we done enough to convince library administrators that collection development is an important, time-consuming and not easily accomplished fact of librarianship. ${ }^{16}$

Particularly in the difficult financial circumstances that many libraries face, having capable selectors doing good collection development is essential. The library needs to have a well-defined, rational, justifiable collection development policy, and everyone-selectors and nonselectors, administrators and nonadministrators-needs to be aware of and supportive of that policy. Selectors need to be well trained in the art of collection development and in the needs and goals of the library and the parent institution.

If selectors are also reference librarians, they need to feel that the time they devote to collection development is well spent and not time taken away from important reference activities. While striking a balance between collection development and reference duties is not an easy task, some compromise must be struck if we are to give part-time selectors the time and support they need to develop and manage good, coherent, well-planned collections.

\section{REFERENCES AND NOTES}

1. See Bonita Bryant, "Allocation of Human Resources for Collection Development," Library Resources \& Technical Services 30:149-62 (Apr./June 1986); Bonita Bryant, "The Organizational Structure of Collection Development," Library Resources \& Technical Services 31:111-22 (Apr./June 1987); Jeanne Sohn, "Collection Development Organizational Patterns in ARL Libraries," Library Resources \& Technical Services 31:123-34 (Apr./June 1987).

2. Laurie S. Linsley, "The Dual Job Assignment: How It Enhances Job Satisfaction," in Academic Libraries: Myths and Realities: Proceedings of the Third National Conference of the Association of College and Research Libraries, ed. Suzanne C. Dodson and Gary L. Menges (Chicago: The Association, 1984), p.148; Nancy J. Emmick and Luella B. Davis, "A Survey of Academic Library Reference Service Practices: Preliminary Results," $R Q$ 24:74-75 (Fall 1984); Paula D. Watson, "Organization and Management of Reference Services in Academic Research Libraries: A Survey," RQ 23:408-9 (Summer 1984); Karen Y. Stabler, "Introductory Training of Academic Reference Librarians: A Survey," RQ 26:366 (Spring 1987). 
3. Phillis E. Jaynes, “Organizational Response to a Changing Environment: The Library's Brave New World," in Academic Libraries: Myths and Realities: Proceedings of the Third National Conference of the Association of College and Research Libraries, ed. Suzanne C. Dodson and Gary L. Menges, (Chicago: ACRL, 1984), p.100. Many people would also include cataloging as one of the functions in an integrated approach. See also Charles R. Martell, Jr., The Client-Centered Academic Library: An Organizatonal Model (Westport, Conn.: Greenwood, 1983) and Judy Reynolds and Jo Bell Whitlach, "Academic Library Services: The Literature of Innovation," College \& Research Libraries 46:402-17 (Sept. 1985).

4. Patricia K. Swanson, "Traditional Models: Myths and Realities," in Academic Libraries: Myths and Realities: Proceedings of the Third National Conference of the Association of College and Research Libraries, ed. Suzanne C. Dodson and Gary L. Menges (Chicago: ACRL, 1984), p.90.

5. Sohn, "Collection Development," p.130-31. For actual organization charts, see Collection Development Organization and Staffing in ARL Libraries, SPEC Kit 131 (Washington, D.C.: Assn. of Research Libraries, Office of Management Studies, 1987).

6. See, for example, Sharon W. Propas, "Cincinnnati Collection Management and Development Institute, November 6-9, 1983 the LAPT Report," Library Acquisitions: Practice and Theory 8:58 (1984) on Ross Atkinson's defense of full-time bibliographers, and Larry Earl Bone, "Noblesse Oblige: Collection Development as a Public Service Responsibility," Reference Librarian 9:65-73 (Fall/Winter 1983) as a defense of the joint responsibility.

7. Emmick, "Survey," p. 75. See also Bryant, "Allocation," p. 151. For a discussion of some of the problems in defining reference work, see Joanne R. Euster, "Helping the Manager Manage: Defining Reference Services," Reference Librarian 3:35-37 (Spring 1982).

8. Anthony W. Ferguson and John R. Taylor, "'What Are You Doing?' An Analysis of Activities of Public Service Librarians at a Medium-Sized Research Library," Journal of Academic Librarianship 6:25 (Mar. 1980).

9. See Sohn, "Collection Development" p.128.

10. Ibid., p.126-27.

11. For an interesting discussion of power and authority in libraries see Charles Martell, "The Nature of Authority and Employee Participation in the Management of Academic Libraries," College \& Research Libraries 48:110-22 (Mar. 1987).

12. Joanne R. Euster and Peter D. Haikalis, " A Matrix Model of Organization for a University Library Public Services Division," in Academic Libraries: Myths and Realities: Proceedings of the Third National Conference of the Association of College and Research Libraries, ed. Suzanne C. Dodson and Gary L. Menges (Chicago: ACRL, 1984), p.358. See also Nancy A. Brown, "Managing the Coexistence of Hierarchical and Collegial Governance Structures," College \& Research Libraries 46:478-82 (Nov. 1985).

13. Euster, "Matrix," p. 359-60, and David W. Lewis, "An Organizational Paradigm for Effective Academic Libraries," College \& Research Libraries 47:337-53 (July 1986). The Lewis article is also one of the best on the management alternatives available to academic libraries.

14. Bette Ann Stead and Richard W. Scamell, "A Study of the Relationship of Role Conflict, the Need for Role Clarity, and Job Satisfaction for Professional Librarians, " Library Quarterly 50:310-23 (July 1980). This article provides a good overview of the major personnel literature on role conflict/ambiguity as does Harold V. Hosel, "Academic Librarians and Faculty Status; A Role Stress-Job Satisfaction Perspective," Journal of Library Administration 5:57-66 (Fall 1984). Two of the better personnel articles are Jone L. Pearce, "Bringing Some Clarity to Role Ambiguity Research," Academy of Management Review 4:665-74 (Oct. 1981) and Ricky W. Griffin, Ann Welsh, and Gregory Moorhead, "Perceived Task Characteristics and Employee Performance: A Literature Review," Academy of Management Review 6:655-64 (Oct. 1981).

15. Diane C. Parker and Eric J. Carpenter, "A Zero-Based Budget Approach to Staff Justification for a Combined Reference and Collection Development Department," in New Horizons for Academic Libraries: Papers Presented at the First National Conference of the Association of College and Research Libraries Boston Massachusetts Nov. 8-11 1978, ed. Robert D. Stueart and Richard D. Johnson (New York: K.G. Saur, 1979), p.478.

16. Maureen L. Gleason, "Training Collection Development Librarians, " Collection Management 4:1-8 (Winter 1982) is one of the better articles on training for collection development. 